Journal of Zhejiang University-SCIENCE B (Biomedicine \& Biotechnology) ISSN 1673-1581 (Print); ISSN 1862-1783 (Online)

www.jzus.zju.edu.cn; www.springerlink.com

E-mail: jzus@zju.edu.cn

\title{
Review:
}

\section{An overview of COVID-19}

\author{
Yu SHI ${ }^{1}$, Gang WANG ${ }^{1}$, Xiao-peng CAI ${ }^{1}$, Jing-wen $\mathrm{DENG}^{1}$, Lin $\mathrm{ZHENG}^{2}$, \\ Hai-hong ZHU ${ }^{1}$, Min ZHENG ${ }^{\dagger 1}$, Bo YANG ${ }^{\dagger \neq 2}$, Zhi CHEN ${ }^{\dagger+1,3}$ \\ ${ }^{1}$ State Key Laboratory for Diagnosis and Treatment of Infectious Diseases, National Clinical Research Center for Infectious Diseases, \\ Collaborative Innovation Center for Diagnosis and Treatment of Infectious Diseases, the First Affiliated Hospital, \\ School of Medicine, Zhejiang University, Hangzhou 310003, China \\ ${ }^{2}$ School of Pharmaceutical Sciences, Zhejiang University, Hangzhou 310058, China \\ ${ }^{3}$ Health Policy and Hospital Management Research Center, School of Medicine, Zhejiang University, Hangzhou 310058, China \\ †E-mail: minzheng@zju.edu.cn; yang924@zju.edu.cn; chenzhi@zju.edu.cn \\ Received Feb. 29, 2020; Revision accepted Mar. 9, 2020; Crosschecked Apr. 14, 2020; Published online May 8, 2020
}

\begin{abstract}
Pneumonia caused by severe acute respiratory syndrome coronavirus 2 (SARS-CoV-2) infection emerged in Wuhan City, Hubei Province, China in December 2019. By Feb. 11, 2020, the World Health Organization (WHO) officially named the disease resulting from infection with SARS-CoV-2 as coronavirus disease 2019 (COVID-19). COVID-19 represents a spectrum of clinical manifestations that typically include fever, dry cough, and fatigue, often with pulmonary involvement. SARS-CoV-2 is highly contagious and most individuals within the population at large are susceptible to infection. Wild animal hosts and infected patients are currently the main sources of disease which is transmitted via respiratory droplets and direct contact. Since the outbreak, the Chinese government and scientific community have acted rapidly to identify the causative agent and promptly shared the viral gene sequence, and have carried out measures to contain the epidemic. Meanwhile, recent research has revealed critical aspects of SARS-CoV-2 biology and disease pathogenesis; other studies have focused on epidemiology, clinical features, diagnosis, management, as well as drug and vaccine development. This review aims to summarize the latest research findings and to provide expert consensus. We will also share ongoing efforts and experience in China, which may provide insight on how to contain the epidemic and improve our understanding of this emerging infectious disease, together with updated guidance for prevention, control, and critical management of this pandemic.
\end{abstract}

Key words: Coronavirus disease 2019 (COVID-19); Severe acute respiratory syndrome coronavirus 2 (SARS-CoV-2); Pathogenesis; Epidemiology; Prevention and management

https://doi.org/10.1631/jzus.B2000083

\section{Introduction}

The global epidemic of coronavirus disease 2019 (COVID-19) has presented a major threat to public health worldwide. COVID-19 is the result of infection with severe acute respiratory syndrome coronavirus 2 (SARS-CoV-2) that was first isolated and identified in patients who were exposed at a seafood market in

\footnotetext{
Corresponding authors

(DD ORCID: Zhi CHEN, https://orcid.org/0000-0002-0848-1502

(C) Zhejiang University and Springer-Verlag GmbH Germany, part of Springer Nature 2020
}

CLC number: R511

Wuhan City, Hubei Province, China on December 2019 (Zhu N et al., 2020). Similar to findings related to SARS-CoV (Drosten et al., 2003; Ksiazek et al., 2003) and Middle East respiratory syndrome coronavirus (MERS-CoV) (Zaki et al., 2012), SARS-CoV-2 is believed to cross species to initiate primary human infections; it is now spread primarily by human-tohuman transmission. Although the case fatality rate of COVID-19 (estimated at 2\%-3\%) is lower than those of SARS (approximately 10\%) and MERS (approximately $40 \%$ ), the pandemic associated with COVID-19 has been far more severe. As of Mar. 15, 2020, 
SARS-CoV-2 has spread rapidly to 34 provinces and cities in China; infection has been reported in 144 countries/territories/areas across five continents (World Health Organization, 2020). The COVID-19 epidemic represents a substantial challenge for governments, individuals, and society as a whole.

This review summarizes the latest findings and expert consensus as it relates to the virology, immunology, epidemiology, clinical features, diagnosis, and management of COVID-19. Our aim is to provide the most up-to-date understanding of both the virus and the disease, as well as to provide ongoing guidance for its prevention, control, and management.

\section{Virology and immunology}

\subsection{Structure of coronavirus}

There are four main subgroups of coronaviruses $(\alpha, \beta, \gamma$, and $\delta)$. There are six members of the $\alpha$ coronavirus group, including human pathogens Cov229E and CoV-HKU1. The $\beta$ coronavirus group includes the human pathogens CoV-OC43, SARS-CoV, and MERS-CoV (King et al., 2012; Lefkowitz et al., 2018). SARS-CoV-2 is also a $\beta$ coronavirus; the amino acid sequences within the seven conserved domains within the genomic open reading frame $1 \mathrm{ab}$ (ORF1ab) are $94.6 \%$ identical to that of the original SARS-CoV (Zhou P et al., 2020b).

The coronavirus virion particle is typically round or multi-shaped. It measures $120-160 \mathrm{~nm}$ in diameter and includes a petal-shaped projection consisting of a triple Spike (S) protein, which is common a feature of the coronaviruses. The $\mathrm{S}$ protein mediates virus attachment and membrane fusion during infection (King et al., 2012). In addition to the characteristic S protein, coronavirus genomes generally encode three additional structural proteins, including the Membrane (M) protein, the Envelope (E) protein, and the Nucleocapsid (N) protein. The coronavirus M protein, 218 to 263 amino acids (aa), has an N-terminus modified by an $O$ - or $N$-glycan and a hydrophilic C-terminal tail. The E protein, 74-109 aa, may be involved in promoting virulence; there are typically about 20 copies of this protein per virion. The coronavirus $\mathrm{N}$ protein, 349 to 470 aa, is an RNA-bound phosphorylated protein that facilitates appropriate folding of genomic RNA into the nucleocapsid (King et al., 2012).

\subsection{Genomic characterization of SARS-CoV-2}

The SARS-CoV-2 virion has a diameter of 60$140 \mathrm{~nm}$ and a positive-sense, single-stranded $29891 \mathrm{bp}$ RNA genome (Zhou P et al., 2020b). Genome sequence alignment has revealed a $79.5 \%$ sequence identity between SARS-CoV-2 and SARS-CoV and a remarkable $93.1 \%$ identity with the sequence of the RaTG12 virus isolated from a bat (Rhinolophus affinis) residing in Yunnan Province, China (Chan et al., 2020a; Zhou P et al., 2020b); these latter results suggest that SARS-CoV-2 may originate from a virus that is endemic in this bat species. Comparative genomic analysis primarily based on sequence inserts identified in the $\mathrm{S}$ protein of a coronavirus isolated from the pangolin (Order, Pholidota; Family, Manidae) suggested that these mammals were most likely the intermediate hosts for cross-species transmission (Liu et al., 2019; Zhang T et al., 2020).

A comprehensive analysis of the SARS-CoV-2 genome together with that of SARS-CoV revealed the presence of nearly thirty ORFs and two novel insertions (Cui HZ et al., 2020). The genome analyses of SARS-CoV and bat coronaviruses indicate that the sequences of ORF6,ORF8, and the $S$ gene display a comparatively low degree of sequence conservation among coronaviruses in general. However, the genomes of bat-SL-CoVZC45 (GenBank ID: MG772933), bat-SL-CoVZXC21 (GenBank ID: MG772934) and RaTG13 (GenBank ID: MN996532) viruses are overall quite similar to that of SARS-CoV-2, most notably with respect to ORF8 (Chan et al., 2020b; Chen LJ et al., 2020; Cui HZ et al., 2020). There are currently several characterized $O R F 8$ variants encoded by the SARSCoV-2 genome (Ceraolo and Giorgi, 2020; Chan et al., 2020b; Cui HZ et al., 2020; Dong et al., 2020; Zhou P et al., 2020b). The full implications of these observations await further understanding of the function of $O R F 8$ within SARS-CoV-2. Likewise, the primary host source of SARS-CoV-2 should be confirmed in the near future.

\subsection{Infectious characteristics of SARS-CoV-2 S protein}

Similar to what was ultimately found for SARS$\mathrm{CoV}$, the binding of SARS-CoV-2 S protein to its cell surface receptor, angiotensin converting enzyme 2 (ACE2), initiates viral entry into type II pneumocytes in the human lung (Gallagher and Buchmeier, 2001). As such, the $\mathrm{S}$ protein plays a central role in the initial 
transmission and ongoing infection of SARS-CoV-2. The coronavirus $\mathrm{S}$ protein includes two main domains: the $\mathrm{S} 1$ domain at the N-terminus of the protein mediates binding to ACE2 and the C-terminal S2 domain promotes fusion of the virus membrane with cellular membrane of the host cell (Hofmann and Pöhlmann, 2004; $\mathrm{Li}, 2016$ ). The receptor-binding domain (RBD) is a subdomain of S1 that includes 424-494 aa. This motif comes into direct contact with the extracellular binding site on ACE2 known as the peptidase domain (PD) (Li et al., 2005; Wrapp et al., 2020). There are two cleavage sites in the $\mathrm{S}$ protein, arginines R667 and R797. The R667 site is at the division between S1 and S2 and cleavage at the R797 site results in the final S2 polypeptide (Millet and Whittaker, 2015). Numerous cellular proteases can cleave the S sequence at these two sites, including cathepsin L, trypsin, elastase, serine transmembrane proteases (TMPRSSs), and factor Xa, among others. Cleavage at both $\mathrm{S}$ protein sites is essential to promote entrances of SARS-CoV and SARS-CoV-2 into the host cell; the first is critical for S1 binding to ACE2 and the second is essential for membrane fusion (Li, 2016; Millet and Whittaker, 2015).

\subsubsection{Binding motif in the S protein of SARS-CoV-2}

The amino acid sequence of the SARS-CoV-2 $\mathrm{S}$ protein shares only limited homology with that of SARS-CoV; the degree of similarity is quite low within the $\mathrm{S} 1$ domain (64\%) and comparatively high within the S2 domain (up to 90\%). Within the S1 domain, the N-terminal region is overall less conserved (51\%), while the C-terminal RBD subdomain has relatively high conservation $(74 \%)$, thereby permitting interactions with the same cell surface receptor ACE2 (Jaimes et al., 2020). There are four to five distinct changes in amino acid sequence within the S1 RBD domain of SARS-CoV-2 compared to SARS-CoV. These amino acids include X442, F472, $\mathrm{C} 479$, and $\mathrm{N} 487$ that are included in the $\mathrm{S}$ protein sequence of SARS-CoV-2 (Zhou P et al., 2020b). These changes within a critical motif in S1 RBD domain may serve to influence receptor-mediated binding and ultimately the transmissibility of the new coronavirus. Several groups have already explored this issue. For example, Wrapp et al. (2020) found that binding of quantities as low as $15 \mathrm{nmol} / \mathrm{L}$ of the $\mathrm{S} 1$ domain of SARS-CoV-2 could be detected at the ACE2 using optical biosensing via surface plasmon resonance.
These results suggest that the $\mathrm{S}$ protein of SARSCoV-2 has a 10-20 fold higher affinity for this receptor than does that of SARS-CoV. Interestingly, in silico analysis of the interactions of ACE2 and the S protein of SARS-CoV-2 led to different conclusions (Huang and Herrmann, 2020; Lan et al., 2020), although these results remain to be confirmed by in vitro and in vivo experiments.

2.3.2 Effect of insertions within the $\mathrm{S}$ protein sequence on SARS-CoV-2 infectivity

SARS-CoV-2 is a highly transmissible coronavirus; evaluation of transmission rates suggests that this may be 3- and 10-fold higher than those of SARS-CoV and MERS, respectively (Jiang and Shi, 2020). The transmissibility of SARS-CoV-2 is directly associated with the sequence of the $\mathrm{S}$ protein, which includes one of the sequence insertions detected in the genome of SARS-CoV-2 (Heurich et al., 2014; Millet and Whittaker, 2015). A four-residue insertion has been found in the S protein directly adjacent to the cleavage site (Meng et al., 2020). TMPRSSs have been identified as contributing to both SARS-CoV and MERS-CoV infections; TMPRSS and TMPRSS11a can catalyze the cleavage of the $S$ protein to $S 1$ and $S 2$ (or S2') domains at the sites of both R667 and R797 residues (Heurich et al., 2014; Millet and Whittaker, 2015). In combination with R685, the four amino acids in the insertion, P681, R682, R683, and A684, can form an exposed loop; this will result in an increased sensitivity to proteases. The insert sequence has also generated a cleavage site for the protease, furin (Jaimes et al., 2020; Meng et al., 2020). Hoffmann et al. (2020) and Meng et al. (2020) confirmed that TMPRSS1 and TMPRSS2 may be the proteases activating $\mathrm{S}$ protein and then contributing to SARS-CoV-2 binding and cell entry. Furthermore, Jaimes et al. (2020) and Walls et al. (2020) reported that the loop formed by the inserted residues increased $\mathrm{S}$ protein susceptibility to protease-mediated cleavage, which facilitated SARSCoV-2 infection. The insertion sequence is unique and has not been found in any other known coronaviruses, not even RaTG12 coronavirus from the bat (Jaimes et al., 2020; Zhou P et al., 2020b).

\subsection{Pathology and disease pathogenesis}

An autopsy report of a 50-year old male patient revealed many details of the condition of the lungs 
of those suffering from the most critical forms of COVID-19. This patient died due to acute respiratory distress syndrome (ARDS) with features that included desquamation of pneumocytes, hyaline membrane formation, and interstitial inflammation and infiltration of large numbers of lymphocytes. Additionally, viral cytopathic-like changes, including multi-nucleated syncytial cells and atypical enlarged pneumocytes, were detected in the intra-alveolar spaces (Xu Z et al., 2020).

The pathogenesis of COVID-19 is largely unknown, but it may mimic SARS to some extent. The viral infection is cytopathic to human airway epithelial cells and alveolar cells as well. However, similar to what was observed in response to SARS-CoV, immune-mediated injury may play a critical role in the pathogenesis of COVID-19, notably among those who are critically ill due to severe disease. Viral infection of pneumocytes induces local inflammatory responses and promotes the release of cytokines, including transforming growth factor- $\beta 1$ (TGF- $\beta 1$ ), tumor necrosis factor- $\alpha$ (TNF- $\alpha$ ), interleukin- $1 \beta$ (IL-1 $\beta$ ), IL-6, as well as numerous chemokines that serve to recruit circulating leukocytes (Razzaque and Taguchi, 2003). In severe forms of COVID-19, the ensuing inflammatory cascade may lead to a cytokine storm, as observed in a recent study that documented elevated serum cytokine levels, including IL-2, IL-7, IL-10, granulocyte colony-stimulating factor (G-CSF), monocyte chemotactic protein (MCP), and TNF- $\alpha$ (Huang et al., 2020). The cytokine storm is believed to be a key factor driving both ARDS and extra-pulmonary organ failure ( $\mathrm{Li}$ and $\mathrm{Xu}, 2010$ ).

Peripheral lymphopenia is commonly observed, notably in association with the more severe form of COVID-19. This observation may reflect functional compartmentalization due to the apparent recruitment of these cells into virus-infected lung tissue rather than any specific virus-mediated suppression $(\mathrm{Xu} \mathrm{Z}$ et al., 2020). Despite reductions in the total number, there is clearly an increased proportion of activated HLA$\mathrm{DR}^{+} \mathrm{CD} 38^{+} \mathrm{T}$ cells in peripheral blood. Similarly, there is an increase in the fraction of $\mathrm{CCR} 4^{+} \mathrm{CCR} 6^{+} \mathrm{Th} 17$ cells, a subgroup of $\mathrm{CD}^{+} \mathrm{T}$ cells with cytotoxic functions similar to those characterized for $\mathrm{CD} 8^{+} \mathrm{T}$ cells (Xu Z et al., 2020). As such, these primary data suggest a critical role for $\mathrm{T}$ cells in modulating the COVID-19-related lung inflammatory response, although mechanistic studies performed with appropriate animal models and human lung specimens will most certainly be needed to evaluate this issue further.

\section{Epidemiology}

\subsection{Basic links to the SARS-CoV-2 epidemic}

\subsubsection{Source of infection}

The infectious sources of SARS-CoV-2 are infected animal hosts and other humans. Bats are considered to be the most likely initial hosts of SARSCoV-2, while pangolins may be the intermediate hosts. Likewise, both symptomatic and asymptomatic patients are known to be contagious. However, it is not clear how long virus shedding persists and how transmissibility might be altered during the natural history of the disease.

The Chinese Center for Disease Control and Prevention (CDC) analyzed environmental specimens and animal samples from Huanan Seafood Market and several other fresh markets in Wuhan, China. The results revealed that $94 \%$ of SARS-CoV-2 nucleic acid-positive samples (31/33 cases) came from the western part of the Huanan Seafood Market, which includes facilities that provide wild animals for purchase. Bats are natural hosts of many of the known coronaviruses (de Wit et al., 2016). As noted earlier, SARS-CoV-2 is a $\beta$ coronavirus; sequence similarities between SARS-CoV-2 and $\beta$ coronaviruses isolated from bat species can be as high as $89.0 \%$ (Zhu N et al., 2020) to $96.2 \%$ (Zhou P et al., 2020b), which indicates that SARS-CoV-2 may be derived from a predecessor coronavirus endemic in bats. Moreover, comparative studies revealed that the similarity between the nucleic acid sequences of the genomes of SARS-CoV-2 and SARS-CoV reached 79.5\%, notably $73.8 \%-74.9 \%$ at the two receptor domains, both of which share ACE2 as a common receptor (Zhou P et al., 2020b; Zhu $\mathrm{N}$ et al., 2020). Interestingly, the genomes of SARS-CoV-2 and the bat coronaviruses also differ, with about $1100 \mathrm{bp}$ nucleotide divergence (Zhou P et al., 2020b). It is also critical to recognize that the major outbreak emerged during the winter when bats are hibernating. As such, the data suggest that there may be one or more intermediate hosts that link the bat coronaviruses to those transmitted to humans. 
Results from a study by Ji et al. (2020) suggested that the SARS-CoV-2 intermediate host might be snakes; however, this contention has been questioned by many experts, given that snakes are cold-blooded animals (Class, Reptilia) whereas the intermediate hosts of SARS and MERS, the civet and the camel, respectively, are both homeothermic. The study of Guo et al. (2020), which featured deep learning algorithms, suggested that minks (Order, Carnivora) may serve as the potential intermediate host, but no experimental evidence was provided to support this hypothesis. The pangolin is currently considered to be the most likely among the candidate intermediate hosts. A research team from the South China Agricultural University (Guangzhou, China) has identified a coronavirus strain from pangolins, which has $99 \%$ sequence similarity with SARS-CoV-2 (Kong, 2020). The current leading hypothesis is that the bat-derived virus evolved to infect pangolins; after a series of mutations and recombination events, it has been transmitted to humans However, the data from this research study have not been published yet. Meanwhile, Lam et al. (2020) have identified a coronavirus strain in the Malay pangolin with a genome that was similar to that of SARSCoV-2 at $85.5 \%-92.4 \%$. Of note, the Malay pangolin $\mathrm{GD} / \mathrm{P} 1 \mathrm{~L}$ and $\mathrm{GD} / \mathrm{P} 2 \mathrm{~S}$ coronaviruses are closely related to SARS-CoV-2. These results suggest that the pangolin may be a long-term host of these pathogens. Furthermore, a team from the China Animal Health and Epidemiology Center (Qingdao, China) tested more than 4800 poultry and livestock samples, and ruled out the possibility that SARS-CoV-2 could have its origins in poultry or livestock (Zhao and Lv, 2020).

With the closure of the Huanan Seafood Market and animal trading markets in most regions of China, wild animals are no longer the main source of infection. Human subjects infected with SARS-CoV-2 are currently the main sources of ongoing infection (General Office of National Health Commission of the People's Republic of China, 2020; Huang et al., 2020). In particular, asymptomatic patients constitute an unpredictable and insidious transmission source that cannot be identified promptly. The unknown numbers of those with asymptomatic infection may explain why SARS-CoV-2 seems to be more contagious than SARS-CoV, the transmission of which is largely limited to symptomatic patient sources. The transmission capacity of asymptomatic patients has been supported by a recent study that revealed that the dynamics of virus shedding was indistinguishable in a comparison between asymptomatic and symptomatic individuals (Zou et al., 2020). This study also demonstrated that higher viral loads were a characteristic of the early stage of disease and were more readily detected from specimens on nasopharyngeal swabs than on oropharyngeal swabs. It is not at all clear at this time how long the capacity to transmit virus persists, but two independent studies reported that infected individuals can transmit virus during both the incubation (Rothe et al., 2020; Xu Z et al., 2020) and recovery periods (Rothe et al., 2020). These critical observations need to be confirmed in larger studies.

\subsubsection{Routes of transmission}

Respiratory droplet and contact transmission are the main transmission routes for person-to-person spread of SARS-CoV-2. Other potential routes include aerosol and fecal-oral transmissions, which have not yet been confirmed (General Office of National Health Commission of the People's Republic of China, 2020; Special Expert Group for Control of the Epidemic of Novel Coronavirus Pneumonia of the Chinese Preventive Medicine Association, 2020).

Respiratory droplet transmission: Respiratory droplets are believed to be the predominant route of transmission, similar to that observed in other respiratory virus infections.

Contact transmission: Since SARS-CoV-2 was found to persist within the environment of infected individuals in Guangzhou, China (household surfaces, door handles, mobile phones, and such), it is not fairly certain that SARS-CoV-2 can also be transmitted through both direct and indirect contacts with virions (General Office of National Health Commission of the People's Republic of China, 2020). When susceptible individuals come into contact with virus-containing body fluids (sputum, saliva, feces) from humans or animals, SARS-CoV-2 can be transmitted through the oral cavity, nasal cavity, and other mucous membranes. Likewise, when susceptible individuals come into contact with body fluid-contaminated items, indirect transmission of SARS-CoV-2 can occur.

Aerosol transmission: Biological aerosol refers to droplets containing pathogens (viruses or bacteria) that are suspended in the air for a period of time and lose moisture; the remaining proteins and pathogens 
form droplet cores and they are able to transfer some distance along the air currents, resulting in potential long-distance transmission of disease. Patients with severe SARS-CoV-2 infection may shed virus to a greater degree during specific medical interventions (mask ventilation, non-invasive ventilation, and tracheal intubation); this can generate local aerosols, which put others in the environment at greater risk (Wax and Christian, 2020).

Fecal-oral and urinary transmission: Recently, the teams of Lan-juan LI and Nan-shan ZHONG isolated SARS-CoV-2 from the feces and urine of patients with COVID-19. These findings indicate that the virus can survive in the digestive tract and the urethra, and suggest that SARS-CoV-2 could be transmitted via the fecal-oral or urinary route (Fang, 2020; Xinhuanet, 2020). However, how the virus persists in feces and urine is currently under further investigation.

Mother-to-child transmission: On Feb. 6, 2020, Wuhan Tongji Hospital reported that an SARS-CoV-2infected pregnant woman gave birth to a child who tested SARS-CoV-2-positive $36 \mathrm{~h}$ after birth; these results suggested the possibility of mother-to-child transmission. On Feb. 8, 2020 in Zhejiang, a pregnant woman with severe COVID-19 gave birth to a newborn who was negative on multiple subsequent nucleic acid virus tests for SARS-CoV-2. Nonetheless, a recent study revealed that fetal infection could be transmitted in late pregnancy (Chen HJ et al., 2020). These observations may relate to low expression of ACE2 among cells detected at the maternal-fetal interface (Zheng et al., 2020). Overall, there appears to be a minimal risk of fetal infection via known routes of vertical transmission.

Other potential routes of infection: Some researchers have speculated that SARS-CoV-2 could be transmitted through conjunctiva, although a recent study refuted this possibility. In this study, only one of the 67 patients with COVID-19 had conjunctivitis; the virus nucleic acid test of secretions from the conjunctival sac was negative (Zhou YY et al., 2020).

\subsubsection{Population susceptibility}

The population at large is generally susceptible with no predominance of a given sex or age. Among all known patients, those who are older (over 50 years old) accounted for $53.6 \%$ of the reported cases and children ( $<10$ years old) account for only $0.9 \%$; there is a small male predominance at $51.4 \%$ (Special Expert Group for Control of the Epidemic of Novel Coronavirus Pneumonia of the Chinese Preventive Medicine Association, 2020). Patients with underlying co-morbidities (including hypertension, diabetes, pre-existing respiratory infection, cardiovascular disease, and cancer) are more likely to succumb and undergo progression to the more severe forms of COVID-19 and also have a higher risk of developing complications (Guan et al., 2020; Special Expert Group for Control of the Epidemic of Novel Coronavirus Pneumonia of the Chinese Preventive Medicine Association, 2020; Yang Y et al., 2020). In one study, $26 \%$ of infected subjects have at least one underlying comorbidity (Special Expert Group for Control of the Epidemic of Novel Coronavirus Pneumonia of the Chinese Preventive Medicine Association, 2020). Family members of COVID-19 patients as well as medical care providers are at high risk for infection due to more frequent contact with infected patients. Medical staff accounted for $29 \%$ of the COVID-19 patients admitted to the Zhongnan Hospital of Wuhan University between Jan. 1 and 28 of 2020 (Wang DW et al., 2020).

\subsection{COVID-19 epidemic}

\subsubsection{Dissemination process}

On Dec. 26, 2019, Dr. Ji-xian ZHANG in the Hubei Hospital of Integrated Traditional Chinese and Western Medicine identified an elderly couple with pneumonia of unknown etiology, and subsequently found five patients with similar clinical presentations on the next day; most of these individuals reported exposure at the Huanan Seafood Market. On Dec. 29, 2019, she reported this issue to the Hubei Provincial Health and Health Committee (Fan et al., 2020). A retrospective analysis of these initial cases revealed that extensive human-to-human transmission of SARSCoV-2 has taken place in Wuhan since mid-December 2019 (Li et al., 2020). COVID-19 rapidly expanded from the initial sporadic epidemic to a region-limited epidemic and now, a pandemic.

Sporadic epidemic: On Jan. 1, 2020, the Wuhan government announced the closure of the Huanan Seafood Market and strengthened preventive measures put in place at surrounding farmers' markets and public places in Wuhan. Prior to Jan. 1, the disease 
was mainly identified in sporadic epidemics or clusters among people in direct contact with the seafood market. More than half of the cases identified at that time presented with a history of exposure to Huanan Seafood Market (Huang et al., 2020).

Region-limited epidemic: After Jan. 1, 2020, only $8.6 \%$ of reported cases could be directly linked to the Huanan Seafood Market, suggesting that the transmission had shifted to the community. There was clear evidence of cluster transmission in multiple communities and families in Wuhan (Li et al., 2020; $\mathrm{Xu} \mathrm{Z}$ et al., 2020; Zhu N et al., 2020). Because this unfortunately coincided with the Chinese Lunar New Year and a time of substantial travel, the epidemic spread quickly within Hubei Province and other areas of China.

Pandemic: On Jan. 13, 2020, the government of Thailand identified a Chinese visitor who was infected with SARS-CoV-2. Subsequent confirmed cases arose in many countries and regions, marking the beginning of a pandemic (Munster et al., 2020). At present, with the exception of Antarctica, confirmed cases have been identified in all continents of the globe. As of 10 a.m. (Central European Time (CET)) on Mar. 15, 2020, there are 153717 confirmed cases worldwide with 81048 of these cases in China (World Health Organization, 2020).

\subsubsection{Spatial distribution}

In China: As of Mar. 15, 2020, COVID-19 cases have been identified in 34 provincial regions in China. Hubei Province has the largest number of cases (67794), which represents $84 \%$ of all COVID-19 cases in China. Most likely due to their geographical locations that are close to Hubei Province, 9605, 6899, and 6324 cases were reported in Henan, Hunan, and Anhui Provinces, respectively. Guangdong and Zhejiang Provinces have reported 11346 and 5737 confirmed cases, respectively; they are thus ranked 2 nd and 4 th in the total number of COVID-19 cases among all the provinces in China (World Health Organization, 2020).

Globally: COVID-19 has reached global epidemic proportions; there have been many forecasts as to when the peak will be reached. Nan-shan ZHONG (Cyranoski, 2020) estimated that the COVID-19 epidemic would reach its peak at the end of February 2020, but others believe that the epidemic will peak sometime from mid-March to late May 2020. As of Mar.
15,2020 , COVID-19 has been reported in 144 countries/ territories/areas across five continents. The Republic of Korea (8162 cases), Japan (780 cases), and Malaysia (238 cases) reported the most confirmed cases in Asia outside China. A total of 45061 cases were reported in Europe, including Italy (21157 cases), Spain (5753 cases), and France (4469 cases). In region of Americas, the United States of America (1678 cases), Canada (244 cases), and Brazil (121 cases) have each reported cases, as has Australia (Oceania; 249 cases) and Egypt (Africa; 93 case). In addition, a final total of 697 cases were confirmed on the Diamond Princess cruise ship (World Health Organization, 2020).

\section{Government measures to contain COVID-19 in China}

On Jan. 20, 2020, the Chinese government identified COVID-19 as a Class B infectious disease and adopted preventive and containment measures ordinarily used for Class A infectious diseases. The efforts to contain COVID-19 in China followed the essential principles that included identifying and isolating the infectious sources and cutting off the transmission routes.

First, the Huanan Seafood Market, known to be the source of the initial outbreak, was closed and sterilized; all further wild animal transactions were prohibited. On Jan. 23, 2020, the Chinese government closed Wuhan City, an unprecedented and decisive step taken to prevent viral spread to other cities in China, as well as abroad. After the closure of Wuhan City, regular wards in all hospitals, as well as sports stadiums, convention centers, and other public buildings, were renovated into quarantine wards and medical resources nationwide, including medical staff, equipment, and diagnostic agents, were rapidly concentrated in Wuhan. The local government carried out a thorough and rigorous screening to identify all potential infected and infectious individuals and their contacts. Patients diagnosed with COVID-19 were admitted to hospitals or renovated provisional medical shelters, depending on the degree of disease severity at presentation; those whose disease progressed while in medical shelters were transferred to hospitals in a timely manner. All the aforementioned measures 
were enacted to ensure that all the patients were isolated and treated. The general population was instructed to take rigorous personal preventive measures including wearing masks in public places together with frequent hand washing and social distancing. The daily life of residents in Wuhan was ensured by allocation of adequate food supplies and other necessities by the central government.

China's centralized efforts to contain the epidemic have prevented further transmission of COVID-19; there has been a significant decline in newly identified and confirmed cases since Feb. 5, 2020. China's prevention and control strategies represent important experiences that may serve as inspiration for containment policies in other nations suffering the impact of this emerging infectious disease.

\section{Clinical features}

Several published studies have documented the varied degrees of clinical severity of COVID-19 as shown in Table 1 (Chen NS et al., 2020; Guan et al., 2020; Huang et al., 2020; Wang DW et al., 2020; Xu XW et al., 2020; Yang XB et al., 2020; Young BE et al., 2020). The incubation period (initial infection to symptoms) ranges from 0 to $24 \mathrm{~d}$, with an average of 5-7 d (Guan et al., 2020). Individuals of any age are susceptible to infection, including neonates and pregnant women. Most patients present with mild to moderate symptoms. The most common symptoms are fever, dry cough, fatigue; upper respiratory tract symptoms can include pharyngalgia, headaches, and myalgia. There is also one report describing patients with gastrointestinal symptoms, including abdominal pain and diarrhea in children and adolescents (Xu Z et al., 2020). In addition, asymptomatic patients have also been reported, although the frequency of this condition has not yet been determined. Approximately $20 \%$ of COVID-19 patients develop severe respiratory illness, with an overall case-fatality rate of about $2.3 \%$. Patients with severe disease typically present with fever, dry cough, dyspnea, and bilateral pulmonary infiltrates on chest imaging. Complications of COVID-19 include ARDS, respiratory failure, liver injury, acute myocardial injury, acute kidney injury, septic shock, and even multiple organ failure. The risk factors for disease progression have not yet been established; however, preliminary evidence sug- gests that severe disease is more likely to take hold in individuals of older age, male sex, and in those with underlying co-morbidities. A study with 1099 confirmed COVID-19 patients was notable for the fact that about $23 \%$ had one or more underlying diseases, including chronic obstructive pulmonary disease $(1.1 \%)$, hypertension $(14.9 \%)$, diabetes $(7.4 \%)$, coronary atherosclerotic heart disease $(2.5 \%)$, and hepatitis B and liver cirrhosis (2.3\%) (Guan et al., 2020). A national survey involving over 70000 COVID-19 patients reported that more than $80 \%$ of the individuals who succumbed to the disease were older than 60 years of age and more than $75 \%$ had cardio-cerebral-vascular disease and/or diabetes. The milder forms of COVID-19 seem to be more commonplace in regions outside Wuhan; in a series of 62 patients in a cohort study carried out in Zhejiang Province of China, only one COVID-19 patient developed ARDS and none died in response to the disease (Xu XW et al., 2020).

Lymphopenia is frequently identified among COVID-19 patients; the total white blood cell count is generally within normal limits of slightly decreased in mild cases but increased in severe or critically ill patients. Indicators of systemic inflammation, including serum levels of ferritin and C-reactive protein (CRP) as well as erythrocyte sedimentation rate (ESR), can be elevated in association with high levels of circulating pro-inflammatory cytokines and chemokines. Likewise, serum levels of alanine aminotransferase (ALT), aspartate aminotransferase (AST), troponin, and/or creatinine may be elevated in patients with extra-pulmonary systemic complications.

Findings on chest computed tomography (CT) are frequent, reaching nearly $100 \%$ in early reports and over $80 \%$ in a recent cohort of patients outside Wuhan. Several critical points with respect to the lung parenchyma and interstitial tissue have been observed that are directly linked to the stages and severity of the disease. Generally, early lesions were single or multiple and presented as limited patchy shadows with interstitial changes, typically located at in the peripheral lung fields just inside the pleura. Positive bronchus signs and thickening of the blood vessels can be detected. The lesions may progress in both number and scope and ultimately generate multiple ground glass opacities bilaterally, with or without minimal pleural effusion. In severe or critical illness, multi-lobular and diffuse infiltrates can be detected on chest CT; these can evolve rapidly to full lung consolidation. 


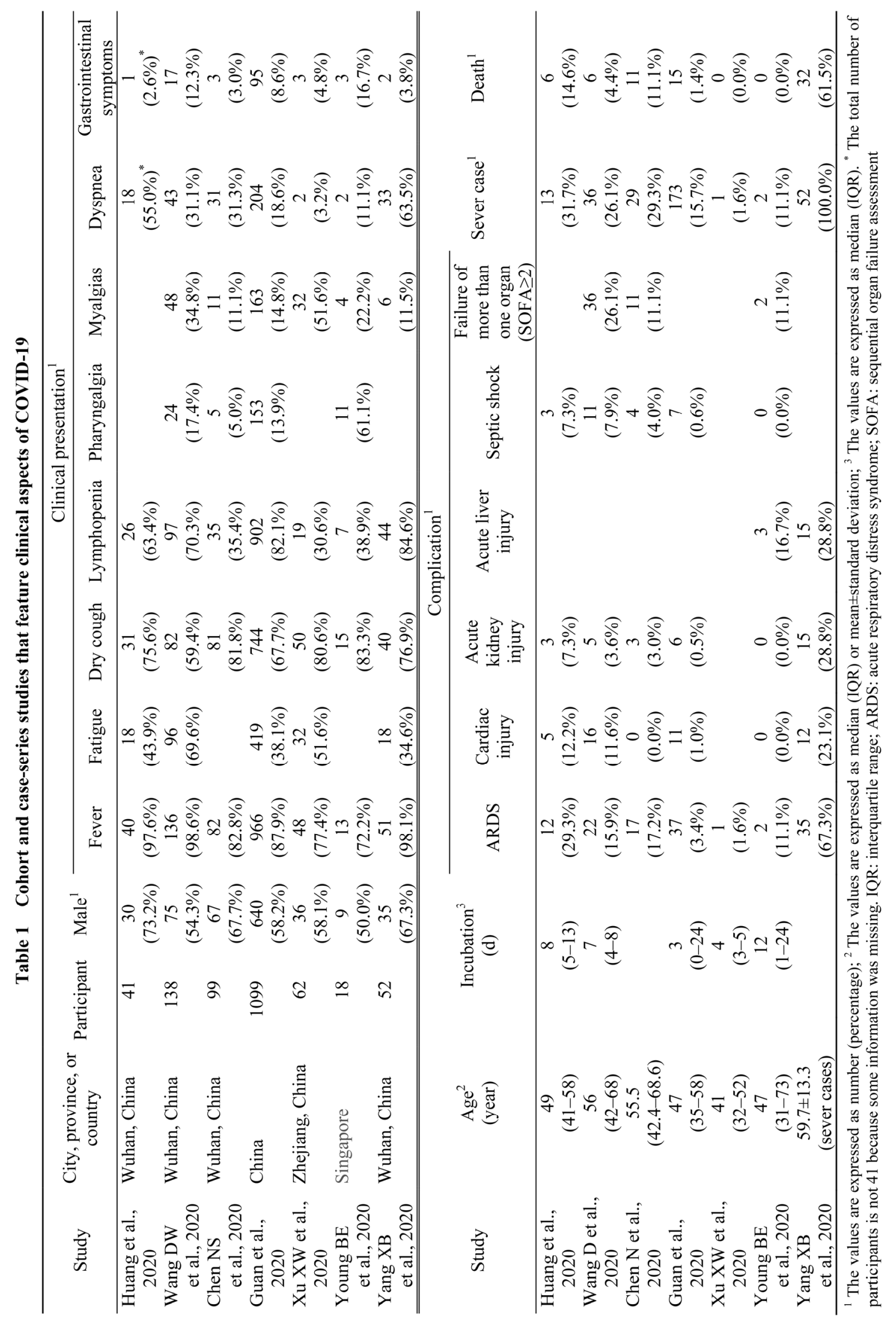




\section{Diagnosis and assessment of severity}

An epidemiological history should be taken for any individual presenting with symptoms suggesting COVID-19; this would include a history of recent travel to or residence in Hubei Province, notably in Wuhan and/or in other areas and communities affected by COVID-19; likewise, information should be carefully checked on close contact with confirmed or probable patients at home, work or health care facilities where hospital-associated cases have been reported in $14 \mathrm{~d}$ prior to symptom onset. A full and complete definitive diagnosis requires isolation of SARS-CoV-2, sequencing of the viral genome, or test of viral nucleic acid by polymerase chain reaction (PCR) in a specimen collected from the upper respiratory tract (nasopharyngeal and oropharyngeal swabs) and if possible, from the lower respiratory tract (sputum, tracheal aspirate, or bronchoalveolar lavage). Tests for other virus pathogens should be conducted simultaneously in order to generate a complete diagnosis.

Isolation of virus from a patient specimen is not routinely recommended because of concern for biosafety. Furthermore, presence of viral nucleic acid in stool has been reported (Xie et al., 2020), although these findings do not constitute a definitive diagnosis. Currently, the nucleic acid test is the most widely used diagnostic approach, but the sensitivity has not been clearly determined. An alternative diagnostic procedure that incorporated symptoms, epidemiological history, and chest CT was applied in Wuhan, given concerns regarding the sensitivity of the nucleic acid test. This diagnostic procedure, which involves no direct virologic evidence, is an effective provisional measure that can be used to identify potential cases in the shortest time possible in an area with a high concentration of cases. However, this methodology will inevitably lead to misdiagnosis.

As shown in Table 2, the spectrum of disease severity can be categorized into patterns that include mild, moderate, severe, and critical illness, as per to the latest national protocol used for the diagnosis and treatment of COVID-19. The natural history of each pattern requires further clarification. For instance, it has not yet been determined what proportion of mild to moderate cases ultimately become severely or critically ill.
Table 2 Criteria for assessing the severity of COVID-19

\begin{tabular}{lc}
\hline Severity & Criteria \\
\hline Mild & Minimal symptoms without pulmonary in- \\
volvement in chest imaging studies & Fever and/or respiratory symptoms; multi- \\
ple limited patchy shadows and intersti- & tial changes in chest imaging \\
Severe & Dyspnea with a respiratory rate of $>30$ breaths \\
& per minute; resting oxygen saturation be- \\
& low $95 \%$ or arterial blood oxygen partial \\
& pressure/oxygen concentration $\leq 300$ mmHg \\
& (1 mmHg=0.133 kPa); multi-lobular disease \\
& or lesion progression of $>50 \%$ within $48 \mathrm{~h} ;$ \\
& sequential organ failure assessment (SOFA) \\
& of $\geq 2$ points; pneumothorax and/or other \\
& clinical conditions requiring hospitalization \\
Respiratory failure requiring mechanical & ventilation; septic shock; additional organ \\
Critically ill & \\
& failure \\
\hline
\end{tabular}

\section{Management}

Currently, disease prevention and control, supportive care, and close monitoring are the essential cornerstone measures for population management of COVID-19. Severe or critically ill patients generally require oxygen therapy and intensive care as the disease frequently progresses to induce complications such as ARDS, respiratory failure, and septic shock. Despite all therapeutic efforts, the mortality rate of patients in an intensive care unit (ICU) setting remains at about $40 \%$. In efforts to reduce mortality related to severe COVID-19, attempts have been made to design therapies that either limit virus replication or modulate the host immune response. Among these, treatment with Arbidol, a broad-spectrum antiviral drug approved for influenza, has been introduced in a cohort of patients admitted to the First Affiliated Hospital of Zhejiang University, Hangzhou, China (Xu KJ et al., 2020). Likewise, systemic glucocorticoids, although controversial, have been explored in a series of patients with mild disease; this modality was well tolerated and viral shedding was not prolonged (unpublished data). A combination of glucocorticoid together with the antiviral immunomodulatory agent, interferon- $\alpha$ (IFN- $\alpha$ ), was also evaluated. Loutfy et al. (2003) reported that glucocorticoids together with IFN- $\alpha$ can quickly reverse pulmonary imaging abnormalities and improve blood oxygen saturation in patients with 
SARS. Similarly, a blood purification treatment method known as Li's artificial liver has been reported to play a beneficial role in alleviating the cytokine storm and can reduce the complications including shock, hypoxemia, and acute respiratory distress in critically ill patients (Xu KJ et al., 2020).

\section{Vaccine development and drugs in the pipeline for COVID-19}

\subsection{Vaccine development}

Vaccine development is a key strategy for preventing widespread viral infection and reducing morbidity and mortality. The novel virus SARS-CoV-2 was first isolated by Chinese scientists; the genome sequence is currently available to the public (Chan et al., 2020b; Zhu N et al., 2020). These advances together with cooperation and open-source data make it possible to design multiple SARS-CoV-2 vaccine candidates.

Vaccines are typically divided into different types, including inactivated vaccines, live attenuated vaccines, vectored vaccines, nucleic acid-based vaccines, and recombinant subunit vaccines (Gao et al., 2019).

\subsubsection{Inactivated vaccines and live attenuated vaccines}

Inactivated and live attenuated vaccines are based on the antigenicity of killed and weakened versions of the virus, respectively. Inactivated vaccines may include whole inactivated virus particles, specific components derived from the virus or toxoids that are chemically modified to destroy their pathogenicity (Stauffer et al., 2006). China National Biotec Group already has some inactivated vaccine candidates available for testing; their immunogenicity and efficacy are currently under evaluation in experimental animals. Live attenuated vaccines are derived from microbial agents that have been weakened via physical, chemical, or biological means under laboratory conditions (Badgett et al., 2002). Codagenix (USA) has formed a collaboration with Serum Institute of India in order to develop a rationally designed live attenuated vaccine against SARS-CoV-2 that is synthesized by viral codon deoptimization.

\subsubsection{Vectored vaccines}

Vectored vaccines are those utilizing other viruses as vectors for SARS-CoV-2 proteins; among such vaccine vectors currently under exploration are the chimeric parainfluenza virus, rabies virus, modified vaccinia Ankara (MVA) virus, vesicular stomatitis virus (VSV), and adenovirus. Scientists of Rocky Mountain Laboratories (USA) and Oxford University (UK) have been collaborating to develop a chimpanzee adenovirusvectored vaccine against SARS-CoV-2. Likewise, Zydus Cadila, an India-based pharmaceutical company, has launched a program to develop a vectored vaccine for the novel coronavirus SARS-CoV-2 using live attenuated recombinant measles virus (rMV); rMV is generated by reverse genetics and expresses codonoptimized proteins of SARS-CoV-2 in order to induce specific neutralizing antibodies.

\subsubsection{Nucleic acid-based vaccines}

Injection of nucleic acid constructs that can express viral or bacterial genes can result in the activation of both humoral and cellular immune responses. Zydus Cadila has a program to develop a DNA vaccine against the major viral membrane $\mathrm{S}$ protein responsible for the cell entry of SARS-CoV-2. After the plasmid DNA is introduced into host cells, it will be translated into the viral protein and elicit immune responses. This provides protection from infection and can lead to viral clearance. Inovio Pharmaceuticals (USA) is currently collaborating with Beijing Advaccine Biotechnology Company (China) to advance the development of INO-4800 as a vaccine candidate targeting SARS-CoV-2. This vaccine is currently undergoing preclinical testing; clinical product manufacturing is in progress for a planned parallel phase I clinical trial in China. Applied DNA Sciences' subsidiary (New York, USA), LineaRx (New York, USA), and Takis Biotech (Rome, Italy) are developing a linear DNA vaccine for the SARS-CoV-2, using PCRbased DNA manufacturing technology. Additionally, Moderna (USA) is also developing a messenger RNA (mRNA) vaccine against SARS-CoV-2 encoding for the viral $\mathrm{S}$ protein, in collaboration with the National Institutes of Health (USA).

\subsubsection{Recombinant subunit vaccines}

Recombinant subunit vaccines are composed of several microbial components produced in a heterologous expression systems (Plotkin, 2005). Compared with inactivated vaccines and live attenuated vaccines, one of the most important advantages of subunit vaccines 
is their significant safety profile as they contain only noninfectious recombinant proteins or synthetic peptides, with no infectious viruses (Zhang et al., 2014). The $\mathrm{S}$ protein of SARS-CoV-2 plays a key role in receptor binding and membrane fusion; as such, vaccines based on the $\mathrm{S}$ protein may be able to induce antibodies to block virus binding and fusion and thus neutralize virus infection (Huang et al., 2020; Ji et al., 2020). The $\mathrm{S}$ protein is one of the most important antigenic components of the coronavirus structural proteins as it can evoke both host immune responses and neutralizing antibodies. It has therefore been selected as a promising target for a vaccine (He and Jiang, 2005). Clover Biopharmaceuticals (Chengdu, China) has initiated the development of a recombinant subunit vaccine for SARS-CoV-2 that utilizes $\mathrm{S}$ protein subunit-trimer antigens.

\subsection{Drugs in the pipeline for COVID-19}

So far there are no specific antiviral measures available to treat COVID-19. Most of the typical options guiding drug manufacture take years of development and are obviously inadequate for the ongoing outbreak. In this situation, studies are often conducted on compassionate use of unproven therapies and clinical trial approvals expedited.

In spite of our limited knowledge, there are several treatment options that could be pursued as first-line therapy for COVID-19. These modalities could be tested rapidly on patients currently diagnosed with SARS-CoV-2 infection.

\subsubsection{Neutralizing antibodies targeting virus $\mathrm{S}$ protein}

ACE2 has been identified as a cellular entry receptor of SARS-CoV-2, similar to that identified for SARS-CoV (Zhou P et al., 2020a). SARS-CoV-2 entry starts with the S protein binding to ACE2 on the cell surface, after which the viral nucleocapsid is delivered into the cell prior to virus replication. The $\mathrm{S}$ protein is involved in receptor recognition as well as virus attachment and entry, both of which are attractive targets for the development of drugs to treat COVID-19. Neutralizing antibodies that target the S protein of SARS-CoV-2 may provide temporary, passive immunity to the disease (Zhao et al., 2016). The full genome sequence of SARS-CoV-2 (GenBank: MN908947.3) was clarified and disclosed to the public shortly after the pandemic originated in Wuhan,
China. This allows scientists to perform gene synthesis in order to express the $\mathrm{S}$ protein as an immunogen (Chan et al., 2020b). CR3022 and CR3014 developed by Crucell (the Netherlands) are human monoclonal antibodies (mAbs) that can neutralize the original SARS-CoV. These mAbs block the interaction between S protein and its cellular receptor ACE2 and thus completely prevent inflammatory pathology in the lungs of SARS-CoV-infected animal models (ter Meulen et al., 2006). Considering that the novel virus SARS-CoV-2 has high sequence similarity to the SARS-CoV virus, these two antibodies may be promising and might be evaluated for the treatment for COVID-19.

\subsubsection{Inhibitors of ACE2}

Given the critical role of ACE2 in the process of virus infection, ACE2 inhibitors may have antiSARS-CoV-2 activity. Thousands of compounds, biologics, and traditional Chinese medicines from databases were screened. Results from these methods suggest that azathioprine, andrographis, urtica, sambucus, astragalus, valproic acid, butyrate, and epoxomicin may be effective strategies toward the development of anti-COVID-19 therapy (Cui QH et al., 2020).

\subsubsection{Oligonucleotides against SARS-CoV-2 RNA} genome

Modalities that target the virus RNA genome, including small interfering RNA (siRNA) and/or antisense oligonucleotides, might be another therapeutic option (Leonard and Schaffer, 2006; Watts and Corey, 2012). However, the appropriate RNA sequence targets of SARS-CoV-2 remain unknown and delivery of oligonucleotides to the lung is also a challenge. As such, gene therapy can be fully applicable for the design of treatments in the current outbreak.

\subsubsection{Repurposing of currently available antiviral drugs}

Small molecule drugs that have already been approved as antiviral (or other) medications may be candidates for COVID-19 treatment. Antivirals typically target viruses at different stages of infection and replication ( $\mathrm{Li}$ and de Clercq, 2020). Viral polymerases and proteases are popular targets for antiviral regimens (Patick and Potts, 1998; Asselah et al., 2009; Lou et al., 2014). Pilot clinical studies have already been performed with the goal of repurposing antiviral drugs. 
There are initial positive reports suggesting that the human immunodeficiency virus (HIV) protease inhibitors, lopinavir and ritonavir, have some clinical efficacy against SARS-CoV-2. These are currently undergoing evaluation in phase III clinical trials (NCT 04252274, NCT04251871, NCT04255017, ChiCTR 2000029539) (Chu et al., 2004; Sheahan et al., 2020). According to the preliminary experiments, darunavir, an anti-HIV drug that targets the viral protease, promoted significant inhibition of SARS-CoV-2 replication. The efficacy and safety of darunavir are planned for an evaluation of this drug together with the licensed anti-HIV drug, cobicistat, for the treatment of COVID-19 in a phase III clinical trial (NCT 04252274).

Arbidol (umifenovir), which has been approved for the treatment of influenza in Russia and China, is effective in vitro against a variety of coronaviruses including SARS-CoV-2 (Chu et al., 2004). As such, arbidol is currently provided to COVID-19 patients as empirical therapy and in phase IV clinical trials (NCT 04260594, NCT04254874, NCT04255017). Another anti-influenza medication favipiravir, an inhibitor of RNA-dependent RNA polymerase (RdRp), is also under consideration for randomized clinical trials for COVID-19 (ChiCTR2000029544, ChiCTR2000029600) (Li et al., 2020; Lu et al., 2020). Given the available knowledge on the safety profiles and efficacy against closely related viruses, existing antiviral agents are potentially helpful short-term strategies to combat SARS-CoV-2.

Remdesivir (Gilead), which is a nucleotide analog prodrug, was originally developed as a drug candidate for use in Ebola virus infection (phase I) (Agostini et al., 2018; Brown et al., 2019; Mulangu et al., 2019). Remdesivir showed positive efficacy against MERS in preclinical models and was administered to the first US case of COVID-19 on a compassionate use basis (Sheahan et al., 2020). Remdesivir is currently under evaluation in hospitalized adult patients with mild to moderate SARSCoV-2 infections in a phase III trial in China (Wang $\mathrm{M}$ et al., 2020).

Chloroquine is another promising therapeutic candidate and has been used widely as a treatment for malaria and infections with amoebae. Chloroquine may have antiviral activity via its capacity to increase the endosomal $\mathrm{pH}$ and thereby inhibits viral fusion events. Other reports suggested that chloroquine could interfere with the glycosylation of cellular receptors of SARS-CoV and would be highly effective at controlling the progression of SARS-CoV-2 infection. Chloroquine showed encouraging anti-SARS-CoV-2 profile in early clinical trials (Wang M et al., 2020).

\subsubsection{Convalescent patient serum}

Patients who have recovered from the SARSCoV-2 infection will develop a polyclonal immune response to viral antigens. These polyclonal antibodies may neutralize virus and prevent further infection in the recovered host (Arabi et al., 2015; Zhao et al., 2015; Al-Tawfiq et al., 2017). Therefore, convalescent patient serum may be a potentially effective tool for treating and preventing further disease related to this outbreak. It was reported that serum from a convalescent SARS patient inhibited SARS-S proteindriven virus entry and reduced SARS-CoV-2 virus entry (Hoffmann et al., 2020). Passive transfer of antibodies from convalescent patient serum is currently under consideration for the treatment of COVID-19 patients with severe disease.

\subsubsection{Traditional Chinese medicine and herbal remedies}

Several kinds of traditional Chinese medicine have documented antiviral and antibacterial properties and been reported as beneficial to the immune system (Jin et al., 2020). According to the advice and guideline for the diagnosis and treatment of pneumonia due to SARS-CoV-2 infection, traditional Chinese medicines would be tailored to match the individual patient signs and symptoms. For patients in different stages of disease, the recommended prescriptions include various ingredients known to practitioners of traditional Chinese medicine as well as Chinese patent medicines such as injections of Xiyanping and Xuebijing, which have been also used for clinical treatment.

Rapid identification and deployment of effective interventions against SARS-CoV-2 infection represent a major challenge. This outbreak has emphasized the urgent need for constant and ongoing efforts to develop vaccines and broad-spectrum antiviral agents that broadly target coronavirus pathogens. With the ongoing efforts to prevent the virus spread and develop helpful drug and vaccine strategies, we hope that the outbreak will subside shortly. 


\section{Conclusions}

Since the outbreak of the COVID-19 epidemic, critical departments have actively responded and coordinated their efforts under the direction of the Chinese government, and medical personnel have risen to the difficulties regardless of personal danger. Although the number of individuals diagnosed with the disease is still rising and has not yet reached its peak, the overall epidemic in China has shown a downward trend. At present, comprehensive surveillance remains critical so as to isolate the source of infection, eliminate the routes of transmission, accelerate diagnosis and treatment of suspected cases, and actively research and take measures to deal with the risks of infection and transmission that may result from the scheduled return to work and school.

Because of the unrelenting efforts of scientific researchers, we have a clear picture of the structure and genetic make-up of the SARS-CoV-2 (Xu XT et al., 2020; Zhou P et al., 2020a) as well as its interactions with a characterized receptor (Yan RH et al., 2020), its host source (Lam et al., 2020; Zhou P et al., 2020b; Zhu N et al., 2020), epidemiological characteristics (Bao et al., 2020; Favre et al., 2020; Huang et al., 2020), and histopathological changes that take place in lung tissue in response to infection (Xu $\mathrm{Z}$ et al., 2020). There are still many urgent questions that need to be answered. Will the virus SARS-CoV-2 mutate to produce new strains? Will COVID-19 persist in our lives and in our hospitals? In addition to the bats (Zhou $\mathrm{P}$ et al., 2020b; Wu et al., 2020) and pangolins (Lam et al., 2020), are there any additional primary and/or intermediate hosts for this virus? What can we do to improve isolation and disinfection? Further research is needed so that we will have a clearer understanding of diagnosis and treatment, prognosis, as well as efforts toward vaccine and drug development. Any solution will be of great significance for overcoming COVID-19 and for preparations for any recurrence.

\section{Contributors}

Yu SHI, Gang WANG, Xiao-peng CAI, Jing-wen DENG, Lin ZHENG, and Hai-hong ZHU were responsible for data collection and article writing. Min ZHENG, Bo YANG, and Zhi CHEN were responsible for conceptualization and manuscript revision. All authors have read and approved the final manuscript.

\section{Compliance with ethics guidelines}

Yu SHI, Gang WANG, Xiao-peng CAI, Jing-wen DENG, Lin ZHENG, Hai-hong ZHU, Min ZHENG, Bo YANG, and Zhi CHEN declare that they have no conflict of interest.

This article does not contain any studies with human or animal subjects performed by any of the authors.

\section{References}

Agostini ML, Andres EL, Sims AC, et al., 2018. Coronavirus susceptibility to the antiviral remdesivir (GS-5734) is mediated by the viral polymerase and the proofreading exoribonuclease. $m B i o, 9(2): \mathrm{e} 00221-18$.

https://doi.org/10.1128/mBio.00221-18

Al-Tawfiq JA, Alfaraj SH, Altuwaijri TA, et al., 2017. A cohort-study of patients suspected for MERS-CoV in a referral hospital in Saudi Arabia. J Infect, 75(4):378-379. https://doi.org/10.1016/j.jinf.2017.06.002

Arabi Y, Balkhy H, Hajeer AH, et al., 2015. Feasibility, safety, clinical, and laboratory effects of convalescent plasma therapy for patients with Middle East respiratory syndrome coronavirus infection: a study protocol. SpringerPlus, 4:709.

https://doi.org/10.1186/s40064-015-1490-9

Asselah T, Benhamou Y, Marcellin P, 2009. Protease and polymerase inhibitors for the treatment of hepatitis $\mathrm{C}$. Liver Int, 29(S1):57-67. https://doi.org/10.1111/j.1478-3231.2008.01928.x

Badgett MR, Auer A, Carmichael LE, et al., 2002. Evolutionary dynamics of viral attenuation. J Virol, 76(20):1052410529 .

https://doi.org/10.1128/jvi.76.20.10524-10529.2002

Bao YP, Sun YK, Meng SQ, et al., 2020. 2019-nCoV epidemic: address mental health care to empower society. Lancet, 395(10224):E37-E38. https://doi.org/10.1016/s0140-6736(20)30309-3

Brown AJ, Won JJ, Graham RL, et al., 2019. Broad spectrum antiviral remdesivir inhibits human endemic and zoonotic deltacoronaviruses with a highly divergent RNA dependent RNA polymerase. Antiviral Res, 169:104541. https://doi.org/10.1016/j.antiviral.2019.104541

Ceraolo C, Giorgi FM, 2020. Genomic variance of the 2019nCoV coronavirus. J Med Virol, 92(5):522-528. https://doi.org/10.1002/jmv.25700

Chan JFW, Yuan SF, Kok KH, et al., 2020a. A familial cluster of pneumonia associated with the 2019 novel coronavirus indicating person-to-person transmission: a study of a family cluster. Lancet, 395(10223):514-523. https://doi.org/10.1016/S0140-6736(20)30154-9

Chan JFW, Kok KH, Zhu Z, et al., 2020b. Genomic characterization of the 2019 novel human-pathogenic coronavirus isolated from a patient with atypical pneumonia after visiting Wuhan. Emerg Microbes Infect, 9(1):221-236. https://doi.org/10.1080/22221751.2020.1719902

Chen HJ, Guo JJ, Wang C, et al., 2020. Clinical characteristics and intrauterine vertical transmission potential of COVID-19 
infection in nine pregnant women: a retrospective review of medical records. Lancet, 395(10226):809-815. https://doi.org/10.1016/s0140-6736(20)30360-3

Chen LJ, Liu WY, Zhang Q, et al., 2020. RNA based mNGS approach identifies a novel human coronavirus from two individual pneumonia cases in 2019 Wuhan outbreak. Emerg Microbes Infect, 9(1):313-319. https://doi.org/10.1080/22221751.2020.1725399

Chen NS, Zhou M, Dong X, et al., 2020. Epidemiological and clinical characteristics of 99 cases of 2019 novel coronavirus pneumonia in Wuhan, China: a descriptive study. Lancet, 395(10223):507-513. https://doi.org/10.1016/s0140-6736(20)30211-7

Chu CM, Cheng VCC, Hung IFN, et al., 2004. Role of lopinavir/ritonavir in the treatment of SARS: initial virological and clinical findings. Thorax, 59(3):252-256. https://doi.org/10.1136/thorax.2003.012658

Cui HZ, Gao ZY, Liu M, et al., 2020. Structural genomics and interactomics of 2019 Wuhan novel coronavirus, 2019$\mathrm{nCoV}$, indicate evolutionary conserved functional regions of viral proteins. bioRxiv, preprint. https://doi.org/10.1101/2020.02.10.942136

Cui QH, Huang CB, Ji XW, et al., 2020. Possible inhibitors of ACE2, the receptor of 2019-nCoV. Preprints, 2020020047. https://doi.org/10.20944/Preprints202002.0047.V1

Cyranoski D, 2020. When will the coronavirus outbreak peak? Nature, Feb. 18, 2020. https://doi.org/10.1038/d41586-020-00361-5

de Wit E, van Doremalen N, Falzarano D, et al., 2016. SARS and MERS: recent insights into emerging coronaviruses. Nat Rev Microbiol, 14(8):523-534. https://doi.org/10.1038/nrmicro.2016.81

Dong N, Yang XM, Ye LM, et al., 2020. Genomic and protein structure modelling analysis depicts the origin and infectivity of 2019-nCoV, a new coronavirus which caused a pneumonia outbreak in Wuhan, China. bioRxiv, preprint. https://doi.org/10.1101/2020.01.20.913368

Drosten C, Günther S, Preiser W, et al., 2003. Identification of a novel coronavirus in patients with severe acute respiratory syndrome. N Engl J Med, 348(20):1967-1976. https://doi.org/10.1056/NEJMoa030747

Fan W, Yang C, Cui M, 2020. The first doctor to report the epidemic: "I realized that something was wrong and I started to prepare." people.cn. http://society.people.com.cn/ n1/2020/0207/c1008-31575058.html [Accessed on Feb. 28, 2020] (in Chinese).

Fang Q, 2020. Nan-shan ZHONG's team isolated neocoronavirus from a patient's urine specimen. Guangzhou Daily. https:/gzdaily.dayoo.com/pc/html/2020-02/23/content_12 7574_683801.htm [Accessed on Feb. 28, 2020] (in Chinese).

Favre G, Pomar L, Musso D, et al., 2020. 2019-nCoV epidemic: what about pregnancies? Lancet, 389(10224):E40. https://doi.org/10.1016/s0140-6736(20)30311-1

Gallagher TM, Buchmeier MJ, 2001. Coronavirus spike proteins in viral entry and pathogenesis. Virology, 279(2):
371-374.

https://doi.org/10.1006/viro.2000.0757

Gao S, Song SQ, Zhang LL, 2019. Recent progress in vaccine development against chikungunya virus. Front Microbiol, 10:2881.

https://doi.org/10.3389/fmicb.2019.02881

General Office of National Health Commission of the People's Republic of China, 2020. Diagnosis and treatment for novel coronavirus (Version 5). http://www.nhc.gov.cn/ xcs/zhengcwj/202002/3b09b894ac9b4204a79db5b8912d 4440.shtml [Accessed on Feb. 28, 2020] (in Chinese).

Guan WJ, Ni ZY, Hu Y, et al., 2020. Clinical characteristics of coronavirus disease 2019 in China. N Engl J Med, in press. https://doi.org/10.1056/NEJMoa2002032

Guo Q, Li M, Wang CH, et al., 2020. Host and infectivity prediction of Wuhan 2019 novel coronavirus using deep learning algorithm. bioRxiv, preprint. https://doi.org/10.1101/2020.01.21.914044

He YX, Jiang SB, 2005. Vaccine design for severe acute respiratory syndrome coronavirus. Viral Immunol, 18(2): 327-332. https://doi.org/10.1089/vim.2005.18.327

Heurich A, Hofmann-Winkler H, Gierer S, et al., 2014. TMPRSS2 and ADAM1 7 cleave ACE2 differentially and only proteolysis by TMPRSS2 augments entry driven by the severe acute respiratory syndrome coronavirus spike protein. J Virol, 88(2):1293-1307. https://doi.org/10.1128/JVI.02202-13

Hoffmann M, Kleine-Weber H, Krüger N, et al., 2020. The novel coronavirus 2019 (2019-nCoV) uses the SARScoronavirus receptor ACE2 and the cellular protease TMPRSS2 for entry into target cells. bioRxiv, preprint. https://doi.org/10.1101/2020.01.31.929042

Hofmann H, Pöhlmann S, 2004. Cellular entry of the SARS coronavirus. Trends Microbiol, 12(10):466-472. https://doi.org/10.1016/j.tim.2004.08.008

Huang CL, Wang YM, Li XW, et al., 2020. Clinical features of patients infected with 2019 novel coronavirus in Wuhan, China. Lancet, 395(10223):497-506. https://doi.org/10.1016/s0140-6736(20)30183-5

Huang Q, Herrmann A, 2020. Fast assessment of human receptor-binding capability of 2019 novel coronavirus (2019-nCoV). bioRxiv, preprint. https://doi.org/10.1101/2020.02.01.930537

Jaimes JA, André NM, Millet JK, et al., 2020. Structural modeling of 2019-novel coronavirus (nCoV) spike protein reveals a proteolytically-sensitive activation loop as a distinguishing feature compared to SARS-CoV and related SARS-like coronaviruses. bioRxiv, preprint. https://doi.org/10.1101/2020.02.10.942185

Ji W, Wang W, Zhao XF, et al., 2020. Homologous recombination within the spike glycoprotein of the newly identified coronavirus may boost cross-species transmission from snake to human. J Med Virol, 92(4):433-440. https://doi.org/10.1002/jmv.25682 
Jiang SB, Shi ZL, 2020. The first disease $\mathrm{X}$ is caused by a highly transmissible acute respiratory syndrome coronavirus. Virol Sin, in press. https://doi.org/10.1007/s12250-020-00206-5

Jin YH, Cai L, Cheng ZS, et al., 2020. A rapid advice guideline for the diagnosis and treatment of 2019 novel coronavirus (2019-nCoV) infected pneumonia (standard version). Mil Med Res, 7(1):4. https://doi.org/10.1186/s40779-020-0233-6

King AMQ, Adams MJ, Carstens EB, et al., 2012. Virus Taxonomy. Ninth Report of the International Committee on Taxonomy of Viruses. Elsevier, San Diego, USA, p.770-783.

Kong LH, 2020. South China Agricultural University: pangolin maybe the intermediate host for new coronavirus. people.cn. http://bj.people.com.cn/n2/2020/0208/c1454033775751.html [Accessed on Feb. 28, 2020] (in Chinese).

Ksiazek TG, Erdman D, Goldsmith CS, et al., 2003. A novel coronavirus associated with severe acute respiratory syndrome. N Engl J Med, 348(20):1953-1966. https://doi.org/10.1056/NEJMoa030781

Lam TTY, Shum MHH, Zhu HC, et al., 2020. Identifying SARS-CoV-2 related coronaviruses in Malayan pangolins. Nature, in press. https://doi.org/10.1038/s41586-020-2169-0

Lan J, Ge JW, Yu JF, et al., 2020. Crystal structure of the 2019-nCoV spike receptor-binding domain bound with the ACE2 receptor. bioRxiv, preprint https://doi.org/10.1101/2020.02.19.956235

Lefkowitz EJ, Dempsey DM, Hendrickson RC, et al., 2018. Virus taxonomy: the database of the International Committee on Taxonomy of Viruses (ICTV). Nucleic Acids Res, 46(D1):D708-D717.

https://doi.org/10.1093/nar/gkx932

Leonard JN, Schaffer DV, 2006. Antiviral RNAi therapy: emerging approaches for hitting a moving target. Gene Ther, 13(6):532-540. https://doi.org/10.1038/sj.gt.3302645

Li CKF, Xu XN, 2010. Host immune responses to SARS coronavirus in humans. In: Lal SK (Ed.), Molecular Biology of the SARS-Coronavirus. Springer, Berlin, Heidelberg, p.259-278. https://doi.org/10.1007/978-3-642-03683-5 16

Li F, 2016. Structure, function, and evolution of coronavirus spike proteins. Annu Rev Virol, 3(1):237-261. https://doi.org/10.1146/annurev-virology-110615-042301

Li F, Li WH, Farzan M, et al., 2005. Structure of SARS coronavirus spike receptor-binding domain complexed with receptor. Science, 309(5742):1864-1868. https://doi.org/10.1126/science.1116480

Li GD, de Clercq E, 2020. Therapeutic options for the 2019 novel coronavirus (2019-nCoV). Nat Rev Drug Dis, 19(3): 149-150. https://doi.org/10.1038/d41573-020-00016-0

Li Q, Guan XH, Wu P, et al., 2020. Early transmission dynamics in Wuhan, China, of novel coronavirus-infected pneumonia. N Engl J Med, 382(13):1199-1207.

https://doi.org/10.1056/NEJMoa2001316

Liu P, Chen W, Chen JP, 2019. Viral metagenomics revealed Sendai virus and coronavirus infection of Malayan Pangolins (Manis javanica). Viruses, 11(11):979. https://doi.org/10.3390/v11110979

Lou ZY, Sun Y, Rao ZH, 2014. Current progress in antiviral strategies. Trends Pharmacol Sci, 35(2):86-102. https://doi.org/10.1016/j.tips.2013.11.006

Loutfy MR, Blatt LM, Siminovitch KA, et al., 2003. Interferon alfacon-1 plus corticosteroids in severe acute respiratory syndrome: a preliminary study. JAMA, 290(24):3222-3228. https://doi.org/10.1001/jama.290.24.3222

Lu RJ, Zhao X, Li J, et al., 2020. Genomic characterisation and epidemiology of 2019 novel coronavirus: implications for virus origins and receptor binding. Lancet, 395(10224): 565-574. https://doi.org/10.1016/s0140-6736(20)30251-8

Meng T, Cao H, Zhang H, et al., 2020. The insert sequence in SARS-CoV-2 enhances spike protein cleavage by TMPRSS. bioRxiv, preprint. https://doi.org/10.1101/2020.02.08.926006

Millet JK, Whittaker GR, 2015. Host cell proteases: critical determinants of coronavirus tropism and pathogenesis. Virus Res, 202:120-134. https://doi.org/10.1016/j.virusres.2014.11.021

Mulangu S, Davey RT Jr, Mbaya OT, et al., 2019. A randomized, controlled trial of Ebola virus disease therapeutics. N Engl J Med, 381(24):2293-2303. https://doi.org/10.1056/NEJMoa1910993

Munster VJ, Koopmans M, van Doremalen N, et al., 2020. A novel coronavirus emerging in China-key questions for impact assessment. $N$ Engl J Med, 382(8):692-694. https://doi.org/10.1056/NEJMp2000929

Patick AK, Potts KE, 1998. Protease inhibitors as antiviral agents. Clin Microbiol Rev, 11(4):614-627. https://doi.org/10.1128/cmr.11.4.614

Plotkin SA, 2005. Vaccines: past, present and future. Nat Med, 11(4):S5-S11. https://doi.org/10.1038/nm1209

Razzaque MS, Taguchi T, 2003. Pulmonary fibrosis: cellular and molecular events. Pathol Int, 53(3):133-145. https://doi.org/10.1046/j.1440-1827.2003.01446.x

Rothe C, Schunk M, Sothmann P, et al., 2020. Transmission of 2019-nCoV infection from an asymptomatic contact in Germany. New Engl J Med, 382(10):970-971. https://doi.org/10.1056/NEJMc2001468

Sheahan TP, Sims AC, Leist SR, et al., 2020. Comparative therapeutic efficacy of remdesivir and combination lopinavir, ritonavir, and interferon beta against MERS-CoV. Nat Commun, 11:222. https://doi.org/10.1038/s41467-019-13940-6

Special Expert Group for Control of the Epidemic of Novel Coronavirus Pneumonia of the Chinese Preventive Medicine Association, 2020. An update on the epidemiological characteristics of novel coronavirus pneumonia (COVID-19). 
Chin J Epidemiol, 41(2):139-144 (in Chinese). https://doi.org/10.3760/cma.j.issn.0254-6450.2020.02.002

Stauffer F, El-Bacha T, da Poian AT, 2006. Advances in the development of inactivated virus vaccines. Recent Pat Anti-Infect Drug Discov, 1(3):291-296. https://doi.org/10.2174/157489106778777673

ter Meulen J, van den Brink EN, Poon LLM, et al., 2006. Human monoclonal antibody combination against SARS coronavirus: synergy and coverage of escape mutants. PLoS Med, 3(7):e237. https://doi.org/10.1371/journal.pmed.0030237

Walls AC, Park YJ, Tortorici MA, et al., 2020. Structure, function and antigenicity of the SARS-CoV-2 spike glycoprotein. Cell, 180:281-292. https://doi.org/10.1016/j.cell.2020.02.058

Wang DW, Hu B, Hu C, et al., 2020. Clinical characteristics of 138 hospitalized patients with 2019 novel coronavirusinfected pneumonia in Wuhan, China. JAMA, 323(11): 1061-1069. https://doi.org/10.1001/jama.2020.1585

Wang M, Cao R, Zhang L, et al., 2020. Remdesivir and chloroquine effectively inhibit the recently emerged novel coronavirus (2019-nCoV) in vitro. Cell Res, 30(3):269-271. https://doi.org/10.1038/s41422-020-0282-0

Watts JK, Corey DR, 2012. Silencing disease genes in the laboratory and the clinic. $J$ Pathol, 226(2):365-379. https://doi.org/10.1002/path.2993

Wax RS, Christian MD, 2020. Practical recommendations for critical care and anesthesiology teams caring for novel coronavirus (2019-nCoV) patients. Can J Anesth/J Can Anesth, 67:568-576. https://doi.org/10.1007/s12630-020-01591-x

World Health Organization, 2020. Coronavirus disease 2019 (COVID-19). Situation Report-55. World Health Organization. https://www.who.int/emergencies/diseases/novelcoronavirus-2019/situation-reports [Accessed on Mar. 16, 2020].

Wrapp D, Wang N, Corbett KS, et al., 2020. Cryo-EM structure of the 2019-nCoV spike in the prefusion conformation. Science, 367(6483):1260-1263. https://doi.org/10.1126/science.abb2507

Wu F, Zhao S, Yu B, et al., 2020. A new coronavirus associated with human respiratory disease in China. Nature, 579(7798):265-269. https://doi.org/10.1038/s41586-020-2008-3

Xie CB, Jiang LX, Huang G, et al., 2020. Comparison of different samples for 2019 novel coronavirus detection by nucleic acid amplification tests. Int J Infect Dis, 93:264-267. https://doi.org/10.1016/j.ijid.2020.02.050

Xinhuanet, 2020. Nan-shan ZHONG's and Lan-juan LI's teams isolated the virus from the stools of patients with new coronary pneumonia. Xinhuanet. http://m.xinhuanet. $\mathrm{com} / \mathrm{hb} / 2020-02 / 13 /$ c_1125570909.htm [Accessed on Feb. 28, 2020] (in Chinese).

Xu KJ, Cai HL, Shen YH, et al., 2020. Management of corona virus disease-19 (COVID-19): the Zhejiang experience. $J$
Zhejiang Univ (Med Sci) (in Chinese).

https://doi.org/10.3785/j.issn.1008-9292.2020.02.02

Xu XT, Chen P, Wang JF, et al., 2020. Evolution of the novel coronavirus from the ongoing Wuhan outbreak and modeling of its spike protein for risk of human transmission. Sci China Life Sci, 63(3):457-460. https://doi.org/10.1007/s11427-020-1637-5

$\mathrm{Xu} \mathrm{XW}, \mathrm{Wu} \mathrm{XX}$, Jiang XG, et al., 2020. Clinical findings in a group of patients infected with the 2019 novel coronavirus (SARS-CoV-2) outside of Wuhan, China: retrospective case series. BMJ, 368:m606. https://doi.org/10.1136/bmj.m606

Xu Z, Shi L, Wang YJ, et al., 2020. Pathological findings of COVID-19 associated with acute respiratory distress syndrome. Lancet Respir Med, 8:420-422. https://doi.org/10.1016/s2213-2600(20)30076-x

Yan RH, Zhang YY, Li YN, et al., 2020. Structural basis for the recognition of the SARS-CoV-2 by full-length human ACE2. Science, 367(6485):1444-1448. https://doi.org/10.1126/science.abb2762

Yang XB, Yu Y, Xu JQ, et al., 2020. Clinical course and outcomes of critically ill patients with SARS-CoV-2 pneumonia in Wuhan, China: a single-centered, retrospective, observational study. Lancet Respir Med, 8(4):e26. https://doi.org/10.1016/s2213-2600(20)30079-5

Yang Y, Lu QB, Liu MJ, et al., 2020. Epidemiological and clinical features of the 2019 novel coronavirus outbreak in China. medRxiv, preprint. https://doi.org/10.1101/2020.02.10.20021675

Young BE, Ong SWX, Kalimuddin S, et al., 2020. Epidemiologic features and clinical course of patients infected with SARS-CoV-2 in Singapore. JAMA, 323(15):14881494. https://doi.org/10.1001/jama.2020.3204

Zaki AM, van Boheemen S, Bestebroer TM, et al., 2012. Isolation of a novel coronavirus from a man with pneumonia in Saudi Arabia. N Engl J Med, 367(19):1814-1820. https://doi.org/10.1056/NEJMoa1211721

Zhang NR, Jiang SB, Du LY, 2014. Current advancements and potential strategies in the development of MERS-CoV vaccines. Exp Rev Vaccin, 13(6):761-774. https://doi.org/10.1586/14760584.2014.912134

Zhang T, Wu QF, Zhang ZG, 2020. Pangolin homology associated with 2019-nCoV. bioRxiv, preprint. https://doi.org/10.1101/2020.02.19.950253

Zhao HJ, Zhou J, Zhang K, et al., 2016. A novel peptide with potent and broad-spectrum antiviral activities against multiple respiratory viruses. Sci Rep, 6:22008. https://doi.org/10.1038/srep22008

Zhao JC, Perera RAPM, Kayali G, et al., 2015. Passive immunotherapy with dromedary immune serum in an experimental animal model for Middle East respiratory syndrome coronavirus infection. $J$ Virol, 89(11):6117-6120. https://doi.org/10.1128/jvi.00446-15

Zhao ZQ, Lv Q, 2020. How is the progress of new coronary pneumonia drugs and vaccines? The scientist came to 
answer the question. people.cn. http://scitech.people.com. $\mathrm{cn} / \mathrm{n} 1 / 2020 / 0215 / \mathrm{c} 1007-31588725 . h t m l$ [Accessed on Feb. 28, 2020] (in Chinese).

Zheng QL, Duan T, Jin LP, 2020. Single-cell RNA expression profiling of ACE2 and AXL in the human maternal-fetal interface. Reprod Dev Med, 4(1):7-10. https://doi.org/10.4103/2096-2924.278679

Zhou P, Yang XL, Wang XG, et al., 2020a. Discovery of a novel coronavirus associated with the recent pneumonia outbreak in humans and its potential bat origin. bioRxiv, preprint. https://doi.org/10.1101/2020.01.22.914952

Zhou P, Yang XL, Wang XG, et al., 2020b. A pneumonia outbreak associated with a new coronavirus of probable bat origin. Nature, 579(7798):270-273. https://doi.org/10.1038/s41586-020-2012-7

Zhou YY, Zeng YY, Tong YQ, et al., 2020. Ophthalmologic evidence against the interpersonal transmission of 2019 novel coronavirus through conjunctiva. medRxiv, preprint. https://doi.org/10.1101/2020.02.11.20021956

Zhu N, Zhang DY, Wang WL, et al., 2020. A novel coronavirus from patients with pneumonia in China, 2019. N Engl J Med, 382(8):727-733. https://doi.org/10.1056/NEJMoa2001017

Zou LR, Ruan F, Huang MX, et al., 2020. SARS-CoV-2 viral load in upper respiratory specimens of infected patients. N Engl J Med, 382(12):1177-1179. https://doi.org/10.1056/NEJMc2001737

\section{中文概要}

\section{题 目: 2019 冠状病毒病 (COVID-19) 概览}

概 要: 2019 年 12 月中国湖北省武汉市爆发由严重急性 呼吸综合征冠状病毒 2(severe acute respiratory syndrome coronavirus 2, SARS-CoV-2）感染引起 的新型冠状病毒肺炎。2020 年 2 月 11 日, 世界 卫生组织 (World Health Organization, WHO) 将 该疾病正式命名为 COVID-19 (coronavirus disease 2019）。COVID-19 临床表现多样, 典型表现为 发热、干咳和乏力, 常出现肺部受累。 SARS-CoV-2 传染性较强, 人群普遍易感。野生 动物宿主和患者为 SARS-CoV-2 主要传染源, 呼 吸道飞沫传播和接触传播为主要传播途径。自发 现该病流行以来, 中国政府和科学界迅速明确了 此次疫情病原体, 并及时向全世界公开病毒基因 序列, 同时采取一系列措施控制疫情。全球科研 工作者从新型冠状病毒肺炎的病原生物学和发 病机制、流行病学、临床特征、诊断治疗和药物 疫苗研发等各方面入手, 开展了一系列研究工 作。本文通过综述最新研究成果、专家共识, 以 及中国抗疫经验, 以期加强对该新发传染病的认 识, 为防控治疗提供参考。

关键词: 2019 冠状病毒病 (COVID-19); 严重急性呼吸 综合征冠状病毒 2(SARS-CoV-2); 发病机理; 流行病学; 预防及治疗 